\title{
Peningkatan Kemampuan Guru Dalam Menggunakan Model Pembelajaran pada Masa Pandemi Covid 19 Melalui Supervisi Akademik di SDN 146/X Tanjung Solok Tahun Ajaran 2021/2022
}

\author{
Neni Rosnita \\ SDN 146/X Tanjung Solok, Jl. Maju Jaya, Tanjung Solok, Jambi, Indonesia \\ neni_rosnita@gmail.com
}

\begin{abstract}
This study aims to obtain information and discuss about improving the ability of teachers to use learning models during the covid 19 pandemic through academic supervision at SDN 146/X Tanjung Solok. This research is school action research which consists of two cycles. This research was carried out at SDN 146/X Tanjng Solok in the odd semester of the 2020/2021 academic year with 7 teachers as research subjects. Data collection techniques using observation, field notes and documentation. Data were analyzed using percentages and data reduction. The results showed that through the application of academic supervision, teachers could improve the ability of teachers to apply learning models at SDN 146/X Tanjung Solok during the covid 19 pandemic.
\end{abstract}

Keywords: Development, Culture, Reading

\begin{abstract}
Abstrak
Penelitian ini bertujuan untuk mendapatkan informasi dan membahas tentang peningkatan kemampuan guru dalam menggunakan model pembelajaran pada masa pandemi covid 19 melalui supervisi akademik di SDN 146/X Tanjung Solok. Penelitian ini merupakan penelitian tindakan sekolah yang terdiri dari dua siklus. Penelitian ini dilaksanakn di SDN 146/X Tanjng Solok pada semester ganjil tahun ajaran 2020/2021 dengan subjek penelitian guru sebanyak 7 orang. Teknik pengumpulan data menggunakan observasi, catatan lapangan dan dokumentasi. Data dianalisis menggunakan persentase dan reduksi data. Hasil penelitian menunjukkan bahwa melalui penerana supervisi akademik dapat meningkatkan kemampuan guru dalam menerapkan modelmodel pembelajaran di SDN 146/X Tanjung Solok pada masa pandemic covid 19.
\end{abstract}

Kata kunci: Teacher Pedagogic Competence, Learning Models, Academic Supervision

Corresponding author: Neni Rosnita

Email Address: neni_rosnita@gmail.com (Jl. Maju Jaya, Tanjung Solok, Jambi)

Received 10 January 2022, Accepted 20 January 2022, Published 27 January 2022

\section{PENDAHULUAN}

Pendidikan merupakan sebuah system kesatuan dari berbagai komponen yang masing-masing memiliki tugas dan fungsikhusus untuk mencapai tujuan bersama. Pendidikan merupakan salah satu aspek pentingdan menjadi faktor utama yang menentukan kualitas sumber daya manusia yang sangat berpengaruh dalam kemajuan pembangunan suatu negara. Kemajuan ilmu pengetahuan dan teknologi, telah memicu perubahan atau peradaban umat manusia yang sangat menakjubkan. Keberhasilan pendidikan dapat dipengaruhi oleh banyak komponen. Salah satu komponen yang sangat berperan dalam menentukan kualitas pendidikan dan keberhasilan proses pembelajaran adalah guru. Keberhasilan pelaksanaan kegiatan belajar mengajar sangat tergantung pada guru, karena guru merupakan ujung tombak dalam proses pembelajaran. Bagaimanapun sempurnanya sebuah kurikulum, tanpa didukung oleh kemampuan guru, makakurikulum itu hanya sesuatu yang tertulis dantidak bermakna. 
Undang-Undang Nomor 20 Tahun 2003 tentang Sistem Pendidikan Nasional menyatakan bahwa pendidikan adalah usaha sadar dan terencana untuk mewujudkan suasana belajar dan proses pembelajaran agar peserta didik secara aktif mengembangkan potensi dirinya untuk memiliki kekuatan spiritual keagamaan, pengendalian diri, kepribadian, kecerdasan, akhlak mulia, serta keterampilan yang diperlukan dirinya, masyarakat, bangsa dan negara. Perlu kita sadari, bahwa peningkatan kualitas komponen-komponen sistem pendidikan yang terbukti lebih berpengaruh terhadap peningkatan mutu pendidikan adalah komponen yang bersifat sumber daya manusia.

Pandemi covid berdampak pada dunia pendidikan, berbagai jenis lembaga pendidikan termasuk madrasah dituntut bersikap adaptif dalam pelaksanaan proses pendidikan. Kepala sekolah memiliki peran krusial dalam peningkatan mutu pendidikan dan kinerja sekolah. Mengacu pada konsep sekolah efektif, Kepala sekolah sebagai pemegang otoritas tertinggi perlu menerapkan kebijakan berorientasi pada visi misi sekolah. Berdasarkan kenyataan itulah, maka guru-guru perlu pembinaan dalam hal ini adalah guru harus disupervisi terus kemampuan profesionalnya. Sebab, dengan supervisi yang terus-menerus, mereka dapat memutakhirkan kemampuan profesionalnya. Dengan kata lain, diperlukan adanya pembinaan yang lebih sistematis, terencana, dan berkelanjutan bagi guru.

Pandemi Covid-19 telah merubah tatanan kehidupan masyarakat, tidak hanya menyerang negara Indonesia namun juga melanda dunia. Keberadaan Covid-19 membuat masyarakat untuk memberhentikan aktivitas di luar rumah yang semestinya dilakukan seperti pada hari-hari biasa. Perubahan sistem pembelajaran menyebabkan kegiatan pembelajaran dan pola supervisi yang dilaksanakan supervisor harus disesuaikan dengan pembelajaran di masa pandemi. Kepala sekolah merupakan seorang pimpinan tertinggi pada suatu satuan pendidikan yang diberi wewenang mengelola personil, dana, maupun sarana. Menurut Iskandar (2013) kepala sekolah pada hakikatnya adalah seorang perencana, organisator, pemimpin dan seorang pengendali di sebuah satuan pendidikan.

Berdasarkan hasil observasi yang dilakukan oleh kepala sekolah di SDN 146/X Tanjung Solok didapat bahwa kebanyakan guru-guru masih menggunkan cara yang monoton dalam mengajar, untuk itu agar semangat dan motivasi siswa kembali bangkit dalam belajar diharapkan guru dapat menggunakan model-model pembelajaran yang menarik minat siswa. Untuk membantu guru dalam menerapkan model-model pembelajarn di kelas tersebut maka diadakan supervise akademik oleh kepala sekolah.

Salah satu kompetensi yang harus dimiliki dan dikuasai kepala sekolah sebagai supervisor pembelajaran di kelas senyatanya yaitu supervisi akademik (Peraturan Menteri Pendidikan dan kebudayaan No. 13 Tahun 2007). Oleh sebab itu kepala sekolah harus memahami konsep-konsep supervisi akademik, sebagai landasan keilmuan tugas kepala sekolah. Dengan memahami konsepkonsep supervisi akademik diharapkan Kepala sekolah dapat melaksanakan tugas sebagai supervisor 
secara profesional sehingga bermuara kepada peningkatan kemampuan profesional guru yang menjadi tanggung jawab kepala sekolah.

Pada hakekatnya bahwa pembelajaran dapat terlaksana apabila terdapat interkasi antar guru dengan siswa serta sarana pendukung pembelajaran, dan salah satu penentu keberhasilan pada kegiatan belajar mengajar adalah guru, malas mengajar dan tidak membuat perangkat pembelajaran, maka apa yang terjadi pada hasil pendidikan adalah siswa akan malas pula belajar. Kenyataan tersebut dalam meningkatkan mutu pendidikan di sekolah maka dibutuhkan adanya supervisi yang profesional yang mampu membimbing, menjadi teladan, dan mampu menggerakkan guru dalam peningkatan mutu pendidikan di sekolah. Dengan demikian, berarti, esensi supervisi akademik itu sama sekali bukan menilai kinerja guru dalam mengelola proses pembelajaran, melainkan membantu guru mengembangkan kemampuan profesionalismenya. Meskipun demikian, supervisi akademik tidak bisa terlepas dari penilaian unjuk kerja guru dalam mengelola pembelajaran. Oleh sebab itu, setiap Kepala sekolah harus memiliki keterampilan teknikal berupa kemampuan menerapkan teknik-teknik supervisi yang tepat dalam melaksanakan supervisi akademik. Teknik-teknik supervisi akademik meliputi dua macam, yaitu: individual dan kelompok.

Menurut Zulfikar, Yusrizal, (2017) pelaksanaan supervisi akademik oleh kepala sekolah dapat meningkatkan proses pembelajaran jika dilakukan sesuai dengan prinsip-prinsip yang berlaku. Oleh karena itu, kepala sekolah sebagai supervisor dituntut untuk mampu melakukan supervisi akademik bagi guru-guru dalam meningkatkan proses pembelajaran. Guru dalam melaksanakan proses pembelajaran memerlukan bimbingan agar mampu melaksanakan proses pembelajaran sesuai dengan aturan yang berlaku. Melalui supervisi akademik bantuan yang diberikan kepada guru tidak bersifat instruksi atau memerintah, sehingga diharapkan adanya kesediaan untuk menerima perbaikan. Suasana dalam pemberian supervisi adalah suasana yang penuh kehangatan, kedekatan, dan keterbukaan. Penelitian ini bertujuan untuk mendapatkan informasi dan membahas tentang peningkatan kemampuan guru dalam menggunakan model pembelajaran pada masa pandemi covid 19 melalui supervisi akademik di SDN 146/X Tanjung Solok.

Secara etimologi kemampuan terambil dari kata mampu berarti "kuasa (bisa, sanggup) melakukan sesuatu". Kata ini berdekatan artinya dengan kompeten atau kompetensi berarti "kewenangan, (kekuasaan pendidik) untuk menentukan sesuatu. Kemampuan berasal dari kata "mampu" yang berarti kuasa, sanggup melakukan, atau dapat (Hoetomo, 2005;332). Sejalan dengan hal tersebut, Kartini Kartono dan Dali Dula (1987:1) menjelaskan dalam kamus psikologi tentang pengertian kemampuan yaitu istilah umum yang dikaitkan dengan kemampuan atau potensi menguasai suatu keahlian ataupun pemikiran itu sendiri.

Seorang guru atau pendidik haruslah memiliki kemampuan dalam penguasaan ilmu pengetahuan, akan senantiasa menyampaikan ilmu pengetahuan yang dimilikinya serta memberikan bimbingan perbaikan akhlak keluhuran budi pekerti pekerti untuk bisa diserap oleh muridnya sehingga nantinya ilmu pengetahuan tersebut akan semakin dikembangkan oleh peserta didik. 
Kunandar (2008:52) menyatakan bahwa kemampuan adalah suatu yang dimiliki oleh seseorang untuk melakukan tugas dan pekerjaan yang dibebankan kepadanya. Berdasarkan pendapat para ahli diatas dapat disimpulkan bahwa kemampuan guru adalah potensi atau kesanggupan yang dimiliki oleh seorang guru untuk melakukan tugas dan pekerjaan yang dibebankan kepadanya. Supervisi akademik pada dasarnya merupakan bagian dari kajian bidang supervisi, sehingga sebelum menuju pada devinisi supervisi akademik maka kita harus mengetahui apa itu supervsisi secara umum. Seorang supervisor mempunyai posisi dan kedudukan di atas atau lebih tinggi yang bertugas melihat, menilai, mengawasi orang-orang yang disupervisinya dalam menuju suatu perbaikan (Kompri: 2015:193). Menurut (Mukhtar dan Iskandar: 2009:40), secara umum istilah supervisi berarti mengamati, mengawasi, atau membimbing dan menstimulir kegiatan-kegiatan yang dilakukan oleh orang lain dengan maksud untuk mengadakan perbaikan.

Menurut Ngalim Purwanto (2012:76) menyebutkan bahwa supervisi akademik adalah segala bantuan dari para pemimpin sekolah, yang tertuju kepada perkembangan kepemimpinan guru-guru dan personel sekolah lainnya di dalam mencapai tujuan-tujuan pendidikan. Kata kunci dari supervisi adalah memberikan layanan layanan dan bantuan kepada guru-guru, maka tujuan supervisi akademik ialah memberikan layanan dan bantuan untuk meningkatkan kualitas mengajar guru di kelas yang pada gilirannya dapat meningkatkan kualitas mengajar belajar siswa. Bukan saja memperbaiki kemampuan mengajar tetapi juga untuk pengembangan potensi kualitas guru (Sahertian 2000).

Supervisi akademik merupakan usaha yang sifatnya membantu atau melayani guru agar dia dapat memperbaiki, mengembangkan, dan bahkan meningkatkan proses belajar mengajar, serta dapat pula mempersiapkan kondisi belajar siswa yang efektif dan efisien untuk mencapai tujuan dan meningkatkan mutu pendidikan. Syaiful Sagala (2010:156) mengatakan supervisi akademik sama maksudnya dengan konsep supervisi pendidikan (educational supervision) sering disebut pula sebagai instructional supervision atau instructional leadership, yang menjadi fokusnya pada hal ini adalah membantu, menilai, memperbaiki, meningkatkan dan mengembangkan mutu pembelajaran yang dilakukan guru melalui pendekatan bimbingan dan konsultasi dalam kegiatan belajar dan mengajar.

Berdasarkan pendapat ahli di atas dapat disimpulkan bahwa Supervisi Akademik adalah proses pemberian bantuan, pengarahan, dan pembinaan, pengajaran yang ditujukan pada perbaikanperbaikan dan pembinaan aspek pengajaran yang menitik beratkan pengamatan supervisor pada masalah-masalah akademik, yaitu hal-hal yang langsung berada dalam lingkungan kegiatan pembelajaran.

Model pembelajaran sangat erat kaitannya dengan gaya belajar siswa dan gaya mengajar guru. Melalui model pembelajaran, guru dapat membantu siswa untuk mendapatkan informasi, keterampilan, cara berfikir, dan mengekspresikan idennya. Model pembelajaran diartikan sebagai prosedur sistematis dalam mengorganisasikan pengalaman belajar untuk mencapai tujuan belajar. Dapat juga diartikan suatu pendekatan yang digunakan dalam kegiatan pembelajaran. Suprijono (2009:46) menjelaskan model pembelajaran merupakan kerangka konseptual yang melukiskan 
prosedur yang sistematis dalam mengorganisasikan pengalaman belajar untuk mencapai tujuan belajar tertentu, dan berfungsi sebagai pedoman bagi para perancang pembelajaran dan para pengajar dalam merencanakan aktivitas belajar mengajar. Sejalan dengan hal tersebut, Isjoni (2013: 50) menyatakan model pembelajaran adalah suatu pola atau rencana yang sudah direncanakan sedemikian rupa dan digunakan untuk menyusun kurikulum, mengatur materi pelajaran, dan memberi petunjuk kepada pengajar di kelasnya.

Model pembelajaran pada dasarnya merupakan bentuk pembelajaran yang tergambar dari awal sampai akhir yang disajikan secara khas oleh guru. Istarani (2011: 1) model pembelajaran adalah seluruh rangkaian penyajian materi ajaryang meliputi segala aspek sebelum, sedang dan sesudah pembelajaran yang dilakukan guru serta segala fasilitas yang terkait yang digunakan secara langsung atau tidak langsung dalam proses belajar. Sejalan dengan itu, Syaiful Sagala (2005:175) mengemukakan bahwa model pembelajaran adalah kerangka konsepual yang melukiskan prosedur yang sistematis dalam mengorganisasikan pengalaman belajar peserta didik untuk mencapai tujuan belajar tertentu, dan berfungsi sebagai pedoman bagi perancang pembelajaran dan guru dalam merencanakan dan melaksanakan aktivitas belajar mengajar.

Berdasarkan beberapa pendapat yang telah dikemukakan para ahli, peneliti menyimpulkan bahwa model pembelajaran adalah suatu pola pembelajaran yang tergambar dari awal hingga akhir kegiatan pembelajaran yang tergambar dari awal hingga akhir kegiatan pembelajaran yang tersusun secara sistematika dan digunakan sebagai pedoman untuk merencanakan kegliatan pembelajaran untuk mencapai tujuan pembelajaran yang telah ditetapkan.

Penyebaran pandemi virus corona atau COVID-19 telah memberikan tantangan tersendiri bagi lembaga pendidikan di Indonesia. Pandemi covid berdampak pada dunia pendidikan, berbagai jenis lembaga pendidikan termasuk madrasah dituntut bersikap adaptif dalam pelaksanaan proses pendidikan. Kepala sekolah memiliki peran krusial dalam peningkatan mutu pendidikan dan kinerja madrasah. Mengacu pada konsep sekolah efektif, Kepala sekolah sebagai pemegang otoritas tertinggi perlu menerapkan kebijakan berorientasi pada visi misi sekolah

Proses pengembangan kinerja guru terbentuk dan terjadi dalam kegiatan belajar mengajar di tempat mereka bekerja. Selain itu kinerja guru dipengaruhi oleh hasil pembinaan dan supervisi kepala sekolah. Perencanaan pembelajaran merupakan langkah yang sangat penting sebelum pelaksanaan pembelajaran. Perencanaan yang matang diperlukan supaya pelaksanaan pembelajaran berjalan secara efektif. Perencanaan pembelajaran dituangkan ke dalam penyiapan atau penyusuna model pembelajaran. Model pembelajaran dikembangkan oleh guru pada satuan pendidikan.

\section{METODE}

\section{Setting Penelitian}

Penelitian ini merupakan penelitian tindakan sekolah yang terdiri dari dua siklus. Penelitian ini dilaksanakn di SDN 146/X Tanjng Solok pada semester ganjil tahun ajaran 2020/2021 dengan 
Peningkatan Kemampuan Guru Dalam Menggunakan Model Pembelajaran pada Masa Pandemi Covid 19 Melalui Supervisi Akademik di SDN 146/X Tanjung Solok Tahun Ajaran 2021/2022, Neni Rosnita

subjek penelitian guru sebanyak 7 orang. Teknik pengumpulan data menggunakan observasi, catatan lapangan dan dokumentasi. Data dianalisis menggunakan persentase dan reduksi data.

\section{HASIL DAN DISKUSI}

\section{Siklus I}

a. Perencanaan

Berikut ini perencanaan yang disusun untuk melaksanakan supervisi pada siklus I: 1) Mempersiapkan RPP sesuai dengan mata pelajaran, 2) Mempersiapkan lembar informasi tentang supervisi, 3) Mempersiapkan kriteria RPP yang tepat dengan model pembelajarn yang jelas, 4) Mempersiapkan kondisi pelaksanaan belajar mengajar untuk mengimplementasikan RPP dalam kegiatan pembelajaran, 6) Mempersiapkan lembar pelaksanaan supervisi, 7) Mempersiapkan lembar observasi, 8) Mempersiapkan penilaian.

b. Pelaksanaan

Tahap pelaksanaan supervisi akademik di SDN 146/X Tanjung Solok dilaksanakan pada hari sabtu tanggal 11 September 2021 dengan mengadakan pertemuan kepada guru-guru dan menjelaskan mengenai model-model pembelajaran yang dapat dipakai dalam proses pembelajaran. Guru-guru dikumpulan di sebuah ruangan dan diberi materi tentang penggunaan model pembelajaran yang baik sehingga dapat membuat siswa termotivasi dan hasil belajar siswa pun meningkat. Setelah dilaksanakan penyampaian materi mengenai model pembelajaran kemudian guru mengatakan akan melakukan supervise ke kelas masing-masing tanpa memberitahu siapa yang akan disupervisi. Hal ini dilaksanakan guru agar semua guru bersiap dan mempersiapkan diri menggunakan model pembelajaran yang baik dan efektif.

Peneliti melakukan supervisi terhadap 7 orang subjek penelitian yang dilakukan selama 3 hari untuk siklus I. Masing-masing guru disupervisi sesuai dengan jadwal mengajar. Pada saat supervisi guru masuk ke dalam kelas tanpa ada pemberitahuan sebelumnya. Kepala sekolah mencatat seluruh kegiatan guru dalam pembelajaran pada lembar instrumen pelaksanaan observasi kelas sebagai masukan dan pertimbangan untuk pembinaan dalam meningkatkan profesional guru. Selanjutnya pada hari Sabtu tanggal 25 September 2021, 7 orang guru tersebut di minta untuk berkumpul dan diberi pengarahan. Peneliti menjelaskan model-model pembelajaran kooperatif yang dapat digunakan saat mengajar. Dimana model-model tersebut dapat meningkatkan motivasi siswa dan siswa akan lebih bersemangat. Untuk itu pada siklus berikutnya diharapakan guru dapat menerapakn model-model pembelajaran yang bervariasi sesuai dengan materi yang diajarkan.

c. Observasi

Berdasarkan hasil observasi pada siklus I dapat dideskripsikan bahwa penyampaian materi model pembelajarn pada siklus I direspon dengan baik. Sesuai dengan cacatan lapangan yang digunakan pada siklus I sebagai alat pengumpulan data didapat bahwa kemampuan guru dalam menerapakan model pembelajaran masih berada pada kategori kurang. Hasil observasi siklus I dapat 
dilihat pada tabel berikut ini:

Tabel 1. Indikator Penilaian Model Pembelajaran Siklus I

\begin{tabular}{|r|l|c|c|c|}
\hline No & \multicolumn{1}{|c|}{ Indikator } & Jumlah & Rata-Rata & Kriteria \\
\hline 1 & $\begin{array}{l}\text { Kesesuaian antara model dengan tujuan } \\
\text { pembelajaran }\end{array}$ & 20 & 2.86 & Memusakan \\
\hline 2 & Kesesuaian model dengan materi & 19 & 2.71 & Kurang \\
\hline 3 & Model dapat memotivasi belajar siswa & 18 & 2.57 & Kurang \\
\hline 4 & $\begin{array}{l}\text { Model dapat melibatkan siswa dalam } \\
\text { pembelajaran }\end{array}$ & 20 & 2.86 & Memuaskan \\
\hline 5 & $\begin{array}{l}\text { Model dapat mengefektifkan kegiatan } \\
\text { pembelajaran }\end{array}$ & 20 & 2.86 & Memusakan \\
\hline 6 & $\begin{array}{l}\text { Model yang digunakan dapat } \\
\text { meningkatkan hasil belajar siswa }\end{array}$ & 18 & 2.57 & Kurang \\
\hline
\end{tabular}

Berdasarkan tabel di atas dapat disimpulkan bahwa dari 6 indikator yang dinilai rata-rata kriteria penilaian terdapat pada kategori kurang dan memuaskan. Indikator kesesuaian model dengan materi, model dapat memotivasi belajar siswa, dan model yang digunakan dapat meningkatkan hasil belajar siswa berada pada kategori kurang memuaskan, sedangkan indikator kesesuaian antara model dengan tujuan pembelajaran, model dapat melibatkan siswa dalam pembelajaran, dan model dapat mengefektifkan kegiatan pembelajaran berada pada kategori memuaskan. Hal ini dapat disimpulkan bahwa pada siklus I kemampuan guru dalam menggunakan model pembelajaran masih berada dalam kategori kurang dan perlu adanya perbaikan-perbaikan untuk siklus selanjutnya. Selain itu, untuk melihat kemampuan masing-masing guru terhadap penerapan model pembelajarn dapat dilihat pada tabel berikut ini: Berdasarkan tabel di atas dapat disimpulkan bahwa dari 6 indikator yang dinilai ratarata kriteria penilaian terdapat pada kategori kurang dan memuaskan. Indikator kesesuaian model dengan materi, model dapat memotivasi belajar siswa, dan model yang digunakan dapat meningkatkan hasil belajar siswa berada pada kategori kurang memuaskan, sedangkan indikator kesesuaian antara model dengan tujuan pembelajaran, model dapat melibatkan siswa dalam pembelajaran, dan model dapat mengefektifkan kegiatan pembelajaran berada pada kategori memuaskan. Hal ini dapat disimpulkan bahwa pada siklus I kemampuan guru dalam menggunakan model pembelajaran masih berada dalam kategori kurang dan perlu adanya perbaikan-perbaikan untuk siklus selanjutnya. Selain itu, untuk melihat kemampuan masing-masing guru terhadap penerapan model pembelajarn dapat dilihat pada tabel berikut ini:

Tabel 2. Kemampuan Guru terhadap Penerapan Model Pembelajaran Siklus I

\begin{tabular}{|c|l|c|c|l|}
\hline No & Nama Guru & Jumlah & Rata-Rata & Kriteria \\
\hline 1 & Mely Yanti & 17 & 2.83 & Memuaskan \\
\hline 2 & Marwatan & 15 & 2.50 & Kurang \\
\hline 3 & Jamaliah & 18 & 3.00 & Sangat Memuaskan \\
\hline 4 & Ahmad Sanusi & 18 & 3.00 & Sangat Memuaskan \\
\hline 5 & Sahriani & 16 & 2.67 & Kurang \\
\hline
\end{tabular}


Peningkatan Kemampuan Guru Dalam Menggunakan Model Pembelajaran pada Masa Pandemi Covid 19 Melalui Supervisi Akademik di SDN 146/X Tanjung Solok Tahun Ajaran 2021/2022, Neni Rosnita

\begin{tabular}{|l|l|l|l|l|}
\hline 6 & Toni & 15 & 2.50 & Kurang \\
\hline 7 & Yuliyana & 16 & 2.67 & Kurang \\
\hline
\end{tabular}

Berdasarkan tabel di atas dapat dilihat bahwa dari 7 orang guru yang menjadi subjek dalam penelitian ini didapat hasil penilaian terhadap kemampuan guru dalam menerapkan model pembelajaran berada pada kategori yang perlu ditingkatkan lagi. Untuk itu perlu adanya perbaikanperbaikan untuk siklus berikutnya agar hasil yang didapat lebih baik lagi.

d. Refleksi

Pada tahap ini hasil penelitian dianalisis dan disimpulkan berdasarkan hasil monitoring dan perekaman tindakan. Data-data tersebut disusun secara sistematis untuk memperoleh hasil penelitian yang valid, dari hasil tersebut dijadikan sebagai pedoman untuk menyusun rencana tindakan selanjutnya. Tahap refleksi dilaksanakan pada hari Rabu tanggal 29 September 2021yang bertempat di ruangan kepala SDN 146/X Tanjung Solok yang dibantu oleh seorang observer yang bernama Ahmad Sanusi. Berdasarkan hasil pengamatan didapat bahwa kemampuan guru masih berada pada kategori kurang dalam menerapkan model-model pembelajaran. Hal ini dapat dilihat dari hasil observasi pada siklus I. Pada saat mengajat guru juga kurang persiapan dalam menerapkan modelmodel pembelajaran dan menyebabkan siswa juga kurang bersemangat dalam belajar.

Dari temuan-temuan yang ada, maka diperlukan adanya upaya perbaikan untuk meninkatkan kemampuan guru dalam menggunakan metode pembelajaran sehingga penelitian tindakan sekolah dengan menerapkan pendekatan supervisi akademik harus dilanjutkan lagi pada siklus kedua. Untuk mnengatasi masalah tersebut maka pada siklus II penilitia akan membekali kembali guru-guru tersebut dengan model-model pembelajarn yang dapat menarik minat siswa dan dengan dialnjutkan dengan supervisi akademik. Maka adapun yang akan dilakukan pada perbaikan untuk siklus berikutnya adalah memaksimalkan lagi kemampuan guru dalam menggunakan model pembelajaran, menjelaskan kembali kepada guru mengenai bentuk, contoh serta model pembelajaran yang baik dan tepat dalam sebuah proses pelaksanaan pembelajaran, menjelaskan kegunaan supervisi akademik bagi guru, menyiapkan hadiah reward bentuk rasa dalam menimbulkan semangat guru.

\section{Siklus II}

a. Perencanaan

Berikut ini perencanaan yang disusun untuk melaksanakan supervisi pada siklus II: 1) Mempersiapkan RPP sesuai dengan mata pelajaran, 2) Mempersiapkan lembar informasi tentang supervisi, 3) Mempersiapkan kondisi pelaksanaan belajar mengajar untuk mengimplementasikan RPP dalam kegiatan pembelajaran, 4) Mempersiapkan lembar pelaksanaan supervisi, 5) Mempersiapkan lembar observasi, 6) Mempersiapkan penilaian.

b. Pelaksanaan

Tahap pelaksanaan siklus II dilaksanakan pada hari Rabu tanggal 6 Oktober 2021. Pada pertemuan ini peneliti mengumpulkan 7 orang guru yang dijadikan sebagai subjek penelitian untuk 
diberikan penjelasan lebih lanjut mengenai model-model pembelajaran. Salah satu tugas kepala sekolah adalah merencanakan supervisi akademik. Agar kepala sekolah dapat melaksanakan tugasnya dengan baik, maka kepala sekolah harus memiliki kompetensi membuat rencana program supervisi akademik. Pada tahap ini peneliti menlakukan supervise akademik guna melihat kesiapan guru dalam mengajar menggunakan model pembelajaran sebagai alat bantu dalam mengajar. Setelah diadakan pertemuan terhadap 7 orang guru tersebut guru kembali melakukan supervisi ke masing-masing guru saat mengajar.

Siklus II, peneliti memasuki masing-masing kelas tempat guru mengajar dengan membawa lembar observasi penilaian terhadap penerapan model pembelajaran yang digunakan oleh guru saat mengajar. Setiap guru yang disupervisi diamati oleh peneliti. Siklus II guru sudah mulai terlihat mahir dalam menggunkan model pembelajaran. Setelah itu, pada hari Kamis tanggal 21 Oktober 2021 kepal sekolah kembali mengumpulkan guru-guru tersebut dan memberikan pengarahan tentang penggunaan model-model pembelajaran.

c. Observasi

Berdasarkan hasil observasi pada siklus I dapat dideskripsikan bahwa penyampaian materi model pembelajarn pada siklus I direspon dengan baik. Sesuai dengan cacatan lapangan yang digunakan pada siklus II sebagai alat pengumpulan data didapat bahwa kemampuan guru dalam menerapakan model pembelajaran meningkat dari siklus I. Hasil observasi siklus II dapat dilihat pada tabel berikut ini:

Tabel 3. Indikator Penilaian Model Pembelajaran Siklus II

\begin{tabular}{|c|l|c|c|l|}
\hline No & \multicolumn{1}{|c|}{ Indikator } & Jumlah & $\begin{array}{l}\text { Rata- } \\
\text { Rata }\end{array}$ & Kriteria \\
\hline 1 & $\begin{array}{l}\text { Kesesuaian antara model dengan tujuan } \\
\text { pembelajaran }\end{array}$ & 24 & 3.43 & $\begin{array}{l}\text { Sangat } \\
\text { Memuaskan }\end{array}$ \\
\hline 2 & Kesesuaian model dengan materi & 26 & 3.71 & $\begin{array}{l}\text { Sangat } \\
\text { Memuaskan }\end{array}$ \\
\hline 3 & Model dapat memotivasi belajar siswa & 26 & 3.71 & $\begin{array}{l}\text { Sangat } \\
\text { Memuaskan }\end{array}$ \\
\hline 4 & $\begin{array}{l}\text { Model dapat melibatkan siswa dalam } \\
\text { pembelajaran }\end{array}$ & 25 & 3.57 & $\begin{array}{l}\text { Sangat } \\
\text { Memuaskan }\end{array}$ \\
\hline 5 & $\begin{array}{l}\text { Model dapat mengefektifkan kegiatan } \\
\text { pembelajaran }\end{array}$ & 26 & 3.71 & $\begin{array}{l}\text { Sangat } \\
\text { Memuaskan }\end{array}$ \\
\hline 6 & $\begin{array}{l}\text { Model yang digunakan dapat } \\
\text { meningkatkan hasil belajar siswa }\end{array}$ & 22 & 3.14 & Memuaskan \\
\hline
\end{tabular}

Berdasarkan tabel di atas dapat disimpulkan bahwa dari 6 indikator penilaian terhadap penerapan model pembelajaran sudah berada pada kategori sangat memuaskan dengan rata-rata masing-masing indikator meningkat dari siklus I dan hanya satu indikator yang berada pada kategori memuaskan 
yaitu indikator model yang digunakan dapat meningkatkan hasil belajar siswa dengan rata-rata 3.14. Siklus II, peneliti memasuki masing-masing kelas tempat guru mengajar dengan membawa lembar observasi penilaian terhadap penerapan model pembelajaran yang digunakan oleh guru saat mengajar. Setiap guru yang disupervisi diamati oleh peneliti. Siklus II guru sudah mulai terlihat mahir dalam menggunkan model pembelajaran. Selain itu, untuk melihat kemampuan masing-masing guru terhadap penerapan model pembelajarn dapat dilihat pada tabel berikut ini:

Tabel 4. Kemampuan Guru terhadap Penerapan Model Pembelajaran Siklus II

\begin{tabular}{|c|l|c|c|l|}
\hline No & Nama Guru & Jumlah & Rata-Rata & Kriteria \\
\hline 1 & Mely Yanti & 20 & 3.33 & Sangat Memuaskan \\
\hline 2 & Marwatan & 22 & 3.67 & Sangat Memuaskan \\
\hline 3 & Jamaliah & 20 & 3.33 & Sangat Memuaskan \\
\hline 4 & Ahmad Sanusi & 23 & 3.83 & Sangat Memuaskan \\
\hline 5 & Sahriani & 21 & 3.50 & Sangat Memuaskan \\
\hline 6 & Toni & 22 & 3.67 & Sangat Memuaskan \\
\hline 7 & Yuliyana & 21 & 3.50 & Sangat Memuaskan \\
\hline
\end{tabular}

Dari tabel di atas dapat disimpulkan bahwa kemampuan guru terhadap penerapan model pembelajaran terdapat peningkatan dari siklus sebelumnya. Keseluruhan subjek dalam penelitian ini yang berjumlah 7 orang sudah berada dalam kriteria sangat memuaskan.

d. Refleksi

Tahap refleksi siklus II dilaksanakan pada Sabtu 23 Oktober 2021 yang bertempat di ruangan kepala SDN 146/X Tanjung Solok yang dibantu oleh seorang observer yang bernama Ahmad Sanusi. Dari hasil pelaksanaan supervisi akademik pada upaya peningkatan kemampuan guru dalam menggunakan model pembelajaran diketahui bahwa pada siklus II, guru sudah berusaha untuk meningkatkan kemampuannya dalam mengunakan model pembelajaran, dan hasilnya sangat memuaskan. Hasil tindakan siklus II mengalami peningkatan dari siklus I, baik secara kuantitatif maupun secara kualitatif dalam memperbaiki komponen perencanaan maupun pelaksanaannya. Dari temuan-temuan yang ada, maka pelaksanaan penelitian tindakan sekolah dengan menerapkan supervisi akdemis guna meningkatkan kemampuan guru dalam menerapkan model pembelajaran dapat diakhiri pada siklus II. Untuk itu penelitian ini tidak dilanjutkan ke siklus berikutnya.

\section{Diskusi}

Berdasarkan hasil penelitian di atas dapat dilihat bahwa pada siklus I kemampuan guru masih belum mencapai target yang dinginkan. Hal ini ditingkatkan lagi pada siklus II. Supervisi akademik adalah proses membantu guru dalam mengembangkan kemampuannya mengelola proses 
pembelajaran untuk mencapai tujuan pembelajarannya yang dilakukan oleh pengawas dan kepala sekolah. Berdasarkan gambar peningkatan kompetensi guru dalam mengajar diatas, membuktikan bahwa, dengan menerapkan supervisi akademik dapat meningkatkan kompetensi guru dalam pelaksanaan proses pembelajaran. Hal ini dimungkinkan karena adanya kerja sama yang baik antara kepala sekolah sebagai supervisor dengan para guru tersebut, yang didukung oleh adanya motivasi dan bimbingan dari kepala sekolah sehingga para guru memiliki antusiasme yang besar untuk dapat meningkatkan kemampuan mereka masing-masing (Zuraidah, 2018). Dengan demikian supervisi akademik adalah kegiatan pengawasan yang ditujukan untuk memperbaiki kondisi-kondisi dalam upaya meningkatkan kualitas produk didik melalui usaha memotivasi, membina dan mengarahkan orang-orang yang terkait dengan kegiatan akademik.

Hal ini sesuai dengan pernyataan Suriati (2018) bahwa secara konseptual, supervisi akademik adalah serangkaian kegiatan membantu guru mengembangkan kemampuannya mengelola proses pembelajaran demi pencapaian tujuan pembelajaran. Supervisi akademik merupakan upaya membantu guru-guru mengembangkan kemampuannya mencapai tujuan pembelajaran. Dengan demikian, esensi supervisi akademik itu sama sekali bukan menilai kinerja guru dalam mengelola proses pembelajaran, melainkan membantu guru mengembangkan kemampuan profesionalismenya.

Supervisi adalah upaya bantuan yang diberikan kepada guru dalam melaksanakan tugas profesionalnya agar guru mampu membantu para siswanya dalam belajar untuk menjadi lebih baik dari sebelumnya, supervisi merupakan suatu teknis pelayanan profesional dengan tujuan utama mempelajari dan memperbaiki bersama-sama dalam membimbing dan mempengaruhi pertumbuhan anak. Supervisi akademik adalah upaya bantuan yang diberikan kepada guru menitikberatkan pada masalah akademik yaitu berlangsung pada kegiatan pembelajaran.

\section{KESIMPULAN}

Berdasarkan hasil penelitian dan pembahasan dapat disimpulkan bahwa melalui penerapan supervisi akademik dapat meningkatkan kemampuan guru dalam menerapkan model pembelajaran di SDN 146/X Tanjung Solok pada masa pandemic covid 19. Hal ini dapat dilihat dari peningkatan kemampuan guru dalam menerapkan model pembelajarn dari siklus I ke siklus II.

Berkaitan dengan hasil penelitian di atas, maka peneliti memberikan saran-saran sebagai berikut: 1) Bagi Guru; Kemampuan menggunakan model pembelajaran merupakan salah satu kemampuan yang harus dimiliki oleh guru karena akan sangat membantu dalam mencapai target pembelajaran. Jadi sangat bijaksana jika guru berusaha mencari masukan tentang berbagai metode pembelajaran yang disesuaikan dengan tujuan kegiatan yang akan dilakukan tanpa meninggalkan faktor siswa, lingkungan, dukungan media, dan sumber belajar agar hasilnya lebih maksimal, 2) Bagi Komite Sekolah;Sebaiknya komite sekolah memfasilitasi sekolah dengan kegiatan-kegiatan yang dapat meningkatkan profesionalisme guru sehingga mutu sekolah dapat terus ditingkatkan, 3) Bagi 
kepala sekolah; Kepala sekolah disarankan melakukan kegiatan pengembangan bagi semua guru pada peningkatan pemahaman penggunaan media pembelajaran dan pengelolaan kelas.

\section{UCAPAN TERIMA KASIH}

Ucapan terima kasih sangat layak disampaikan untuk semua pihak yang telah membantu dalam pengerjaan artikel ini. Baik teman, dosen, kakak, dan yang lainnya. Artikel ini dapat dibuat karena adanya bantuan mereka. Semoga artikel ini dapat bermanfaaat untuk banyak pihak.

\section{REFERENSI}

Agus Suprijono. (2009). Cooperative Learning: Teori dan Aplikasi PAIKEM. Yogyakarta: Pustaka Pelajar

Hoetomo. (2005). Kamus Lengkap Bahasa Indonesia, Surabaya: PT. Mitra Pelajar

Isjoni. (2013). Cooperative Learning: Mengembangkan Kemampuan Belajar Kelompok. Bandung:

Alfabeta

Iskandar. (2013). Metodologi penelitian pendidikan dan sosial. Jakarta: Gaung Persada Press.

Istarani. (2011). 58 Model Pembelajaran Inovatif (Reverensi Guru Dalam Menentukan Model Pembelajaran). Medan: Media Persada

Kartini Kartono dan Dali Dula. (1987). Kamus Psikologi Pendidikan, Bandung: CV. Pionerjaya

Kompri. (2015). Manajemen Pendidikan: Bandung: Alfabeta

Kunandar. (2008). Guru Profesional Implementasi KTSP dan Sukses dalam Sertifikasi Guru, Jakarta: Grafindo Persada.

Mukhtar dan Iskandar. (2009). Orientasi Baru Supervisi Pendidikan. Jakarta: GP Press

Ngalim Purwanto. (2012). Administrasi dan Supervisi Pendidikan. Bandung: Remaja Rosdakarya.

Peraturan Pemerintah Nomor 19 Tahun 2005 tentang Standar Nasional Pendidikan

Sagala, Syaiful. (2010). Supervisi Pembelajaran dalam Profesi Pendidikan. Bandung: Alfabeta

Sahertian, Piet A. (2000). Konsep Dasar dan Teknik Supervisi akademik. Jakarta: Bineka Cipta

Sudjana. (2005). Metode Statistika. Bandung: Tarsito.

Suriati. (2018). Meningkatkan Kompetensi Guru SDN 007 Kampung Baru Kecamatan Cerenti dalam

Menyusun Perencanaan Pembelajaran Melalaui Supervisi Akademik. Jurnal PAJAR (Pendidikan dan Pengajaran), 2 (2), 269-281.

Syaiful Sagala. (2005). Konsep dan Makna Pembelajaran Untuk Membantu Memecahkan Problematika Belajar dan Mengajar. Bandung: Alfabeta.

Zuraida. (2018). Penerapan Supervisi Akademis Pengawas Sekolah untuk Meningkatkan Kompetensi Pedagogik Guru Non Kependidikan SDN 003 Bagan Hulu Kecamatan Bangko Kabupaten Rokan Hilir. Jurnal PAJAR (Pendidikan dan Pengajaran), 1 (1), 136-141. 
Zulfikar, Yusrizal, \& Ibrahim, S. (2017). Supervisi Akademik oleh Kepala Sekolah dalam Meningkatkan Kompetensi Profesional Guru SD Negeri 2 Calang Kabupaten Aceh Jaya, 5(3), 192-198. 